\title{
New Editor-in-Chief for Plant Cell Reports
}

After more than 6 years of dedicated service, health reasons have forced Michael Horn to retire from his function as Editor-in-Chief for Plant Cell Reports. Plant Cell Reports has undergone a clear evolution during this period. Among the most visible features that have been introduced are the special issues dedicated to topics that merit particular attention and in-depth treatment through original articles, reviews and opinion papers that all shed light on the same question but from different angles. Michael Horn was also at the helm of the latest special issue, dedicated to Molecular Pharming.
Jang R. Liu, principal researcher at the Green Bio Research Center of the Korea Research Institute of Bioscience and Biotechnology (KRIBB), has accepted our invitation to succeed Michael Horn in the function of Editor-in-Chief of Plant Cell Reports, thus allowing the journal to maintain the well-proven organization with a tandem of Editors-in-Chief on two different continents.

Günther Hahne, Editor-in-Chief Jang R. Liu, Editor-in-Chief 